\title{
Gender difference of aging performance decay rate in normalized Masters World Records of Athletics: much less than expected
}

\author{
Paolo Gava (1), Walter Giuriati (2), Barbara Ravara (1,2,3) \\ (1) A\&C M-C Foundation for Translational Myology, Padova, Italy; (2) Interdepartmental \\ Research Center of Myology, Department of Biomedical Science, University of Padova, Italy; \\ (3) Department of Neuroscience, Institute of Human Anatomy, University of Padova, Italy \\ This article is distributed under the terms of the Creative Commons Attribution Noncommercial License (CC BY-NC 4.0) which permits \\ any noncommercial use, distribution, and reproduction in any medium, provided the original author(s) and source are credited.
}

\begin{abstract}
Aging behaviours differ in females and males. Females are weaker but survive longer. We report gender decay of skeletal muscle performance by comparing World Records of Master athletes. Master athletes compete in age groups of 5 years till 100 years. The Master World Records are lists of 16 data that, after normalization, show trends of aging decline of muscle performance indicating only minimal gender differences in the process. All trend-lines tend to zero at about 110 years. Since hormons poorly influence aging performance decay, other fundamental bioregulators, e.g., those of cell energy metabolism, seems to be relevant.
\end{abstract}

Key Words: Aging performance decay, Masters World Records, gender differences

Eur J Transl Myol 30 (1): xx1-xx4, 2020

Aging behaviours are significantly different in females and males, the former having a longer life expectancy, ${ }^{1}$ though having consistently weaker muscle strength. ${ }^{2-4}$ The main purpose of the present study is to establish if this is true also for the decline of performance of aging females in comparison to males. Gava et al. ${ }^{5}$ reported some interesting conclusions analysing the decline of the World Records of male Master athletes in Track and Field competitions, in general agreement with previous studies. ${ }^{6-11}$ Master Athletes are athletes competing within age groups divided into categories of five-year periods, from $35-39,40-44$, and so on, until the age of 110 years. This study compared the declining trends after transformation of the measured athletic performance into a parameter proportional to the power developed by the athlete in carrying out the athletic gesture. This approach, making use of a very homogeneous cohort of testers, gets rid of the main confounding factors in other studies of age-related performance decay, as different length of clinical longitudinal studies, ${ }^{12}$ or different modalities to measure strength, power and resistance to fatigue in aging. ${ }^{13}$ Main conclusion is that the consistent decreased values of all female Master records almost disappear after normalization suggesting that the performance decay is related to fundamental cell bioregulators, such as those of cellular energy metabolism and/or of their epigenetic regulatory mechanisms.

The method required, first, the creation of a database with all the World Records of the main disciplines of athletics:
11 track, 4 throwing and 4 jumping events. ${ }^{5}$ The same Records must also be collected for all categories of the Master Athletes, both females and males (14 categories each). The data collected in this study come from the official archives of the world athletic associations: IAAF, International Association of Athletics Federation (http://www.iaaf.org/) ${ }^{14}$ [for absolute World Records of Senior Athletes], and the World Master Athletics (http://www.world-masters-athletics.org/) ${ }^{15}$ for the World Records of Master Athletes. The database contains about 280 World Records, each associated with the contour data (discipline, performance, athlete's name, athlete's age, athlete's nationality, date of performance, location of the performance). All data used in this study are public data collected in events officially recognized by the relative federation of athletics. One example of the results of the normalization procedure is presented in Table 1, a and b. As one example, Figure 1 presents the comparison of all the 11 running events considered in this study for females (red lines) and males (blue lines). The decline of all the disciplines is very similar and it is very gentle from 30 to 50 years, it is almost linear from 50 to 70 years and then the decay is progressively steeper. Men and women slops are almost overlapping till the age of 50 years, then women are declining a bit more than men. The detailed comparison of the overall decline in different kind of events (not shown) demonstrates that the performances, where explosive power is involved (jumping and throwing events), decline with age faster 
Table 1, a. Senior and Master World Record Performance: $100 \mathrm{~m}$ run and Long Jump of male and female athletes

\begin{tabular}{|c|c|c|c|c|}
\hline Event & $\begin{array}{c}100 \mathrm{~m} \\
\text { male }\end{array}$ & $\begin{array}{c}\text { Long } \\
\text { Jump } \\
\text { male }\end{array}$ & $\begin{array}{c}100 \mathrm{~m} \\
\text { female }\end{array}$ & $\begin{array}{c}\text { Long } \\
\text { Jump } \\
\text { female }\end{array}$ \\
\hline $\begin{array}{c}\text { World } \\
\text { Record }\end{array}$ & 9.58 & 8.95 & 10.49 & 7.52 \\
\hline Master 35 & 9.97 & 8.50 & 10.74 & 6.99 \\
\hline Master 40 & 10.29 & 7.68 & 11.09 & 6.55 \\
\hline Master 45 & 10.72 & 7.77 & 11.34 & 5.62 \\
\hline Master 50 & 10.88 & 6.84 & 11.67 & 5.41 \\
\hline Master 55 & 11.44 & 6.35 & 13.3 & 5.01 \\
\hline Master 60 & 11.7 & 6.07 & 13.75 & 4.75 \\
\hline Master 65 & 12.37 & 5.47 & 14.1 & 4.64 \\
\hline Master 70 & 12.77 & 5.19 & 14.76 & 4.26 \\
\hline Master 75 & 13.49 & 4.83 & 15.91 & 3.77 \\
\hline Master 80 & 14.35 & 4.36 & 18.42 & 3.05 \\
\hline Master 85 & 16.16 & 3.77 & 19.83 & 2.54 \\
\hline Master 90 & 17.53 & 3.26 & 23.18 & 1.77 \\
\hline Master 95 & 20.41 & 2.14 & 15.48 & \\
\hline $\begin{array}{c}\text { Master } \\
100\end{array}$ & 29.83 & & & \\
\hline
\end{tabular}

Table 1,b. Senior and Master World Record after normalization procedure: $100 \mathrm{~m}$ run and Long Jump of male and female athletes

\begin{tabular}{|c|c|c|c|c|}
\hline Event & $\begin{array}{c}100 \mathrm{~m} \\
\text { male }\end{array}$ & $\begin{array}{c}\text { Long } \\
\text { Jump } \\
\text { male }\end{array}$ & $\begin{array}{c}100 \mathrm{~m} \\
\text { female }\end{array}$ & $\begin{array}{c}\text { Long } \\
\text { Jump } \\
\text { female }\end{array}$ \\
\hline $\begin{array}{c}\text { World } \\
\text { Record }\end{array}$ & 1.000 & 1.000 & 1.000 & 1.000 \\
\hline Master 35 & 0.950 & 0.950 & 0.977 & 0.930 \\
\hline Master 40 & 0.950 & 0.858 & 0.946 & 0.871 \\
\hline Master 45 & 0.858 & 0.812 & 0.925 & 0.747 \\
\hline Master 50 & 0.812 & 0.764 & 0.899 & 0.719 \\
\hline Master 55 & 0.764 & 0.709 & 0.789 & 0.666 \\
\hline Master 60 & 0.709 & 0.678 & 0.763 & 0.632 \\
\hline Master 65 & 0.678 & 0.611 & 0.744 & 0.617 \\
\hline Master 70 & 0.611 & 0.580 & 0.711 & 0.566 \\
\hline Master 75 & 0.580 & 0.540 & 0.659 & 0.501 \\
\hline Master 80 & 0.540 & 0.487 & 0.569 & 0.406 \\
\hline Master 85 & 0.487 & 0.421 & 0.529 & 0.338 \\
\hline Master 90 & 0.421 & 0.364 & 0.453 & 0.235 \\
\hline Master 95 & 0.364 & 0.239 & 0.296 & \\
\hline Master & 0.239 & & & \\
\hline 100 & & & \\
\hline
\end{tabular}

than the running performances (lasting at least 10 second or more) for both women and men. Therefore, there are no clear differences between gender in terms of decline across the events; with both women and men following close trends. The results of this kind of analysis about the aging decline in physical performance of skeletal muscle reveal some indisputable elements:

- Despite the differences in absolute performance of female and male skeletal muscles (from 10 to $15 \%$ lower in females $)^{2-4}$ decline in trend with age is very similar.

- The decline of performances in the activities that mainly involve the lower limbs for a non-explosive activity but protracted in time (i.e. all the running events) begins very gently in both females and males. In this type of physical activity (deambulation) the human body decays to $50 \%$ of youth performance at an age between 80 and 90 years, a fact that is not part of the common consensus (Figure 1). It is worth noting that Lepers R, Stapley PJ. (2016) studying gender differences in the limits of human endurance observed that "The relative stability of gender differences ... suggests that the age-related declines in physiological function did not differ between males and females ". 16

- The performance decline in the jumping events (explosive activities that essentially involve the lower limbs) falls almost linearly with age, both in females and males, and falls to $50 \%$ of youth value between 60 and 80 years of age. The dimensionless parametric analysis does not reveal any unexpected peculiarity, in agreement with previous analyses using different approaches. ${ }^{6-11}$

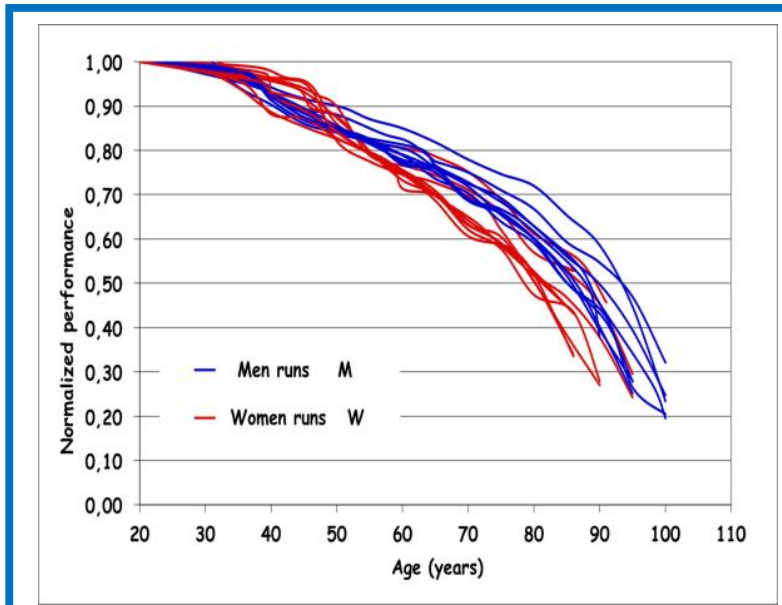

Fig 1. Comparison of normalized running parameters of male and female Masters Athletes. Decline of running disciplines is very similar. It is very gentle from 30 to 50 years, it is almost linear from 50 to 70 years and then the decay is progressively steeper. 
The decay of activities that mainly involve the upper limbs, i.e. the throwing events shows unequivocally a much more marked decline between 40 and 60 years of age, both in females and males, and reaches $50 \%$ of youth value in between 50 and 70 years. In these activities the decline of the females is initially slightly more pronounced than that of males. Quantitative analyses of the eventual statistically significant gender differences are above the scope of this paper and will be performed in the near future, if the described approach will be accepted by the scientific community. Based on the absence of strong evidence on mechanisms related to neuro-humoral gender differences, it could be hypothesized that the aging decline is related to some fundamental cellular mechanisms, specifically, those that control energy metabolism, both directly, ${ }^{17}$ and indirectly, ${ }^{18-20}$ that is, those of cellular energy metabolism and/or of their epigenetic regulatory mechanisms.

In conclusion, all together the analysis of World Records of Master athletes here described is pointing to an absence of main differences in "aging decline" of females and males. This is something fully unexpected in genderrelated sports behaviours. Implications may have longterm influences on biology, physiopathology and managements of aging per se and of its complications

\section{List of acronyms}

IAAF -International Association of Athletics Federation

\section{Authors contributions}

PG played the main role in the conception, study design, and data acquisition, while Barbara Ravara participated in analyses of data and in drafting and finalizing the manuscript.

\section{Acknowledgments}

The Authors thank colleagues of the Interdepartmental Research Center of Myology, Department of Biomedical Science, University of Padova, Italy and of the A\&C MC Foundation for Translational Myology, Padova, Italy for discussions and critical readings.

\section{Funding}

The A\&C M-C Foundation for Translational Myology, Padova, Italy supported BR and sponsored the publication of this manuscript.

\section{Conflict of Interest}

The authors declare they have no financial, personal, or other conflicts of interest.

\section{Ethical Publication Statement}

We confirm that we have read the Journal's position on issues involved in ethical publication and affirm that this report is consistent with those guidelines. The study was approved by the Ethics Committee of "G. d'Annunzio" University (protocol n. 16/2019) and was in accordance to the Declaration of Helsinki..

\section{Corresponding Author}

Barbara Ravara, Interdepartmental Research Center of Myology, Department of Biomedical Science, University of Padova, Via Ugo Bassi, 58/B 35131 Padova, Italy.

ORCID iD: 0000-0002-0159-3245

Email: barbara.ravara@unipd.it

E-mails of co-author

Paolo Gava: paologavamain@gmail.com ORCID iD: 0000-0003-1672-1374

Walter Giuriati: walter.giuriati@unipd.it ORCID iD: 0000000299913488

\section{References}

1. Barford A, Dorling D, Smith G, Shaw M. Life expectancy: women now on top everywhere. BMJ 2006;332(7545):808.

2. Lewis DA, Kamon E, Hodgson JL. Physiological differences between genders. Implications for sports conditioning. Sports Med 1986;3:357-69.

3. Hunter SK, Stevens AA. Sex differences in marathon running with advanced age: physiology or participation? Med Sci Sports Exerc 2013;45:14856. doi: 10.1249/MSS.0b013e31826900f6.

4. Mascherini G, Castizo-Olier J, Irurtia A, et al. Differences between the sexes in athletes' body composition and lower limb bioimpedance values. Muscles Ligaments Tendons J 2018;7:573-81. doi: 10.11138/mltj/2017.7.4.573. eCollection 2017 OctDec.

5. Gava P, Kern H, Carraro U. Age-associated power decline from running, jumping, and throwing male Masters World Records. Exp Aging Res 2015;41:115-35. doi: 10.1080/0361073X.2015.100 1648.

6. Baker AB, Tang YQ. Aging performance for masters records in athletics, swimming, rowing, cycling, triathlon and weightlifting. Exp Aging Res 2010;36:453-77. doi:10.1080/0361073X.2010.507 $433 \mathrm{E}$

7. Böttiger LE. Regular decline in physical working capacity with age. Br Med J 1973:3:270-1.

8. Edmunds K, Gíslason $\mathrm{M}$, Sigurðsson $\mathrm{S}$, et al. Advanced quantitative methods in correlating sarcopenic muscle degeneration with lower extremity function biometrics and comorbidities. PLoS One 2018;13:e0193241. doi: 10.1371/ journal.pone.0193241.

9. Frontera W, Hughes VA, Fielding RA, et al. Aging of skeletal muscle: A 12-yr longitudinal study. J Appl Physiol 2000;88:1321-6.

10. Mitchell WK, Williams J, Atherton P, et al. Sarcopenia, dynapenia, and the impact of advancing age on human skeletal muscle size and strength; a quantitative review. Front Physiol 2012;3:1-18. doi:10.3389/fphys.2012.00260

11. Larsson L, Degens H, Li M, et al. Sarcopenia: Aging-Related Loss of Muscle Mass and Function. 


\section{Gender difference of aging decay in Masters World Records}

Eur J Transl Myol 30 (1): xx1-xx4, 2020

Physiol Rev 2019;99:427-511. doi: 10.1152/ physrev.00061.2017.

12. Young BW, Starkes JL. Career-span analyses of track performance: Longitudinal data present a more optimistic view of age-related performance decline. Exp Aging Res 2005;31:69-90. doi:10. 1080/03610730590882855

13. Runge M, Rittweger J, Russo CR, et al. Is muscle power output a key factor in the age-related decline in physical performance? A comparison of muscle cross section chair-rising test and jumping power. Clin Physiol Funct Imaging 2004;24:335-340.

14. International Association of Athletics Federation http://www.iaaf.org/

15. World Master Atheltics - http://www.worldmasters-athletics.org/

16. Lepers R, Stapley PJ. Master Athletes Are Extending the Limits of Human Endurance. Front Physiol 2016;12;7:613. doi: 10.3389/fphys.2016. 00613. eCollection 2016.

17. Favaro G, Romanello V, Varanita T, et al. DRP1mediated mitochondrial shape controls calcium homeostasis and muscle mass. Nat Commun 2019;10(1):2576. doi: 10.1038/s41467-019-102269.

18. Pigna E, Renzini A, Greco E, et al. HDAC4 preserves skeletal muscle structure following longterm denervation by mediating distinct cellular responses. Skelet Muscle 2018;8:6. doi: 10.1186/ s13395-018-0153-2.

19. Renzini A, Marroncelli N, Noviello C, et al. HDAC4 Regulates Skeletal Muscle Regeneration via Soluble Factors. Front Physiol (2018;9:1387. doi: 10.3389/fphys.2018.01387. eCollection 2018.

20. Seaborne RA, Strauss J, Cocks M, et al. Human Skeletal Muscle Possesses an Epigenetic Memory of Hypertrophy. Sci Rep 2018;8:1898. doi: 10.1038 /s41598-018-20287-3.

Submission: February, 1, 2020

Acceptance: February 11, 2020 